\title{
CORRESPONDENCE
}

The Editors regret that the date of issue at the head of the first Number of the present Volume was printed incorrectly. Volume 105, Number 1, of the Geological Magazine was in fact issued on 3rd April, 1968.

\section{A NEW OCCURRENCE OF CELESTITE, NEAR LLANTRISANT, GLAMORGAN}

SIR,-Immediately south and south-east of the town of Llantrisant, in mid-Glamorgan, an outlier of Dolomitic Conglomerate oversteps successively, from south to north, the uppermost $75 \mathrm{~m}$ (250 feet) of the Main Limestone, an estimated thickness of $60 \mathrm{~m}$ (200 feet) for the Millstone Grit, $105 \mathrm{~m}$ (350 feet) of the full succession of the Lower Coal Measures and the lower-most $90 \mathrm{~m}$ (300 feet) of the Middle Coal Measures to a plane well above the horizon of the Two Feet Nine Seam. The Dolomitic Conglomerate has a maximum thickness of 15 to $18 \mathrm{~m}$ (50 to 60 feet); it shows a generally horizontal attitude with only minor flexures and this contrasts sharply with the consistent northerly dips of 30 to 37 degrees displayed by the under-lying Carboniferous beds (Fig. 1).

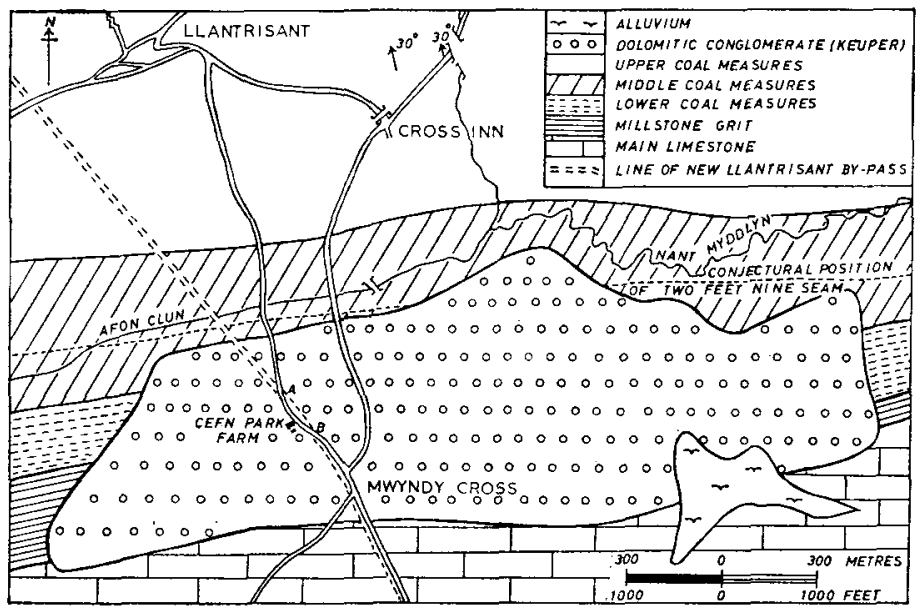

FIG. 1.-Geological map of the area south and south-east of Llantrisant (based largely on published Six Inch Sheets of the Geological Survey).

Until recently, exposures of the Dolomitic Conglomerate were on a rather limited scale, and these were largely overgrown so that few details of the stratigraphical succession and the nature and extent of mineralization could be established. The new Llantrisant by-pass, work on which commenced in 1967, will eventually cut across the full width of this Dolomitic Conglomerate outlier. In a cutting of $135 \mathrm{~m}$ (150 yards), showing a maximum width of about $14 \mathrm{~m}$ ( 45 feet), up to $11 \mathrm{~m}$ ( 35 feet) of Conglomerate is exposed.

Celestite was found throughout the full depth of these new exposures and along their complete lateral extent. It occurs mainly as nodules or geodes. These are generally rounded or slightly ovoid with average long diameters of 3 to $10 \mathrm{~cm}$. Except in the immediate vicinity of clay-filled joints these nodules are tightly welded to the rock and, consequently, are difficult to extract as complete specimens. In the former locations where the joint walls are rotten, and to varying degrees decalcified, larger masses of celestite 15 to $23 \mathrm{~cm}$ in diameter can be detached. The mineral is generally granular, and when in geodal form the internal linings are of highly irregular outline and very brittle. Within the lower massive conglomerates, cavities up to $45 \mathrm{~cm}$ across are lined with twinned scalenohedra or nail-head crystals of calcite and thin films of celestite. At 
this same stratigraphical level a few mineralized nodules show complex admixtures of granular or massive celestite and small platy crystals of barytes.

In the upper half of the section several counts have revealed an average of 60 to 80 of these celestite nodules or geodes to the cubic metre. Local variations in their frequency, both along the general direction of the strike and in depth, are apparent, but these are not sufficiently consistent to suggest limits to the extent of their occurrence.

This new discovery of celestite nodules or geodes within a few metres of the surface is, perhaps, of palaeogeographical significance. It is a possible pointer to the likely existence of a former cover of Keuper Marl, maybe a hundred metres thick. The nodules are in effect pseudomorphs of former dolomitic pebbles or fragments, and it would appear that they were derived by metasomatism associated with descending solutions. Unfortunately, along the full length of the South Crop of the South Wales coalfield within the northern sections of the Vale of Glamorgan, exposures of Keuper Marl, as distinct from the Dolomitic Conglomerate, are very limited, and one is unable to determine whether the former shows occurrences of celestine on a larger scale, possibly in crudely bedded form as near Yate in Gloucestershire.

\section{WELSH OFFICE,}

SUMMTT HOUSE,

WINDSOR PLACE, CARDIFF.

25th January, 1968.

Trevor M. Thomas.

\section{JOINT AND FAULT PATTERNS IN NORTH-EAST TASMANIA}

Sir,-The detailed work of Williams (1967) at Dalrymple Hill, north-east Tasmania, has focused interest on the persistence or re-activation of stress fields that cause jointing and faulting. He has shown that:-

(i) Patterns of joints in Mathinna Beds differ from those in Permian rocks (op. cit., Figs. 4 and 5), and that a large number of joints are usually disposed at 90 degrees to the local fold axis (op. cit., p. 251).

(ii) Joints in the Permian rocks may be correlated with similarly orientated normal faults (op. cit., p. 244).

(iii) Joints in the Permian rocks and in the late Devonian granite yield similar patterns when plotted and contoured on a Lambert projection (op. cit., p. 249).

(iv) The three steep sets of joints in the granite are of similar trends to faults affecting Permian rocks (op. cit., p. 249).

Williams concluded from the foregoing items that (op. cit., p. 251) "No joints in the Siluro-Devonian beds can be attributed to the post-Permian faulting ...", the absence of fractures related to those of the Permian beds being "due to the anisotropy of the Mathinna rocks", that (op. cit., p. 249) "stress fields identical in orientation to those that caused the joints of the Permian rocks also caused those of the granite ", and that (op. cit., p. 251) "faults which dislocate the Permian rocks may have been established earlier and affected the granite before Permian times, resulting in joints of a similar pattern to those in the Permian rocks but of a different age ".

The geology of the Pipers River Quadrangle (Marshall et al., 1965) north-east Tasmania, in many ways approximates that at Dalrymple Hill (Williams, 1967). In the east of the area the late Devonian Scottsdale Batholith (McDougall \& Leggo, 1965) intrudes folded Siluro-Devonian Mathinna Beds, whilst in the west Permo-Triassic rocks unconformably overlie the Mathinna Beds and are intruded by a Jurassic dolerite sheet. A geometric analysis by Marshall (in press) of jointing and folding in the Quadrangle has considerable bearing on the conclusions of Williams (1967). The more pertinent aspects of the results will now be given.

(i) A majority of joints in the Mathinna Beds are approximately at right angles to the local and regionally-defined fold axes. Such a relationship is common in areas of statistically-cylindrical flattened flexural folding.

(ii) The joint pattern in the granodiorite is undistinguishable from Fig. $5 d$ of Williams (1967, p. 248). It is therefore constant over a distance of $64 \mathrm{~km}$ (40 miles) and in a really distinct but coeval granitic masses (McDougall \& Leggo, 1965). 